\title{
Delving deeper: metabolic processes in the metalimnion of stratified lakes
}

Article

Accepted Version

Giling, D. P., Staehr, P. A., Grossart, H. P., Andersen, M. R., Boehrer, B., Escot, C., Evrendilek, F., Gómez-Gener, L., Honti, M., Jones, I. D., Karakaya, N., Laas, A., Moreno-Ostos, E., Rinke, K., Scharfenberger, U., Schmidt, S. R., Weber, M., Woolway, R. I. ORCID: https://orcid.org/0000-0003-0498-7968, Zwart, J. A. and Obrador, B. (2017) Delving deeper: metabolic processes in the metalimnion of stratified lakes. Limnology and Oceanography, 62 (3). pp. 1288-1306. ISSN 0024-3590 doi: https://doi.org/10.1002/Ino.10504 Available at https://centaur.reading.ac.uk/70399/

It is advisable to refer to the publisher's version if you intend to cite from the work. See Guidance on citing.

Published version at: http://dx.doi.org/10.1002/Ino.10504

To link to this article DOI: http://dx.doi.org/10.1002/Ino.10504

Publisher: Wiley

All outputs in CentAUR are protected by Intellectual Property Rights law, including copyright law. Copyright and IPR is retained by the creators or other copyright holders. Terms and conditions for use of this material are defined in the End User Agreement. 


\section{www.reading.ac.uk/centaur}

\section{CentAUR}

Central Archive at the University of Reading

Reading's research outputs online 


\section{Delving deeper: Metabolic processes in the metalimnion of stratified lakes}

2 Darren P. Giling ${ }^{1, *}$, Peter A. Staehr ${ }^{2}$, Hans Peter Grossart ${ }^{1,3}$, Mikkel René Andersen ${ }^{4}$, Bertram

3 Boehrer $^{5}$, Carmelo Escot ${ }^{6}$, Fatih Evrendilek ${ }^{7}$, Lluís Gómez-Gener ${ }^{8}$, Mark Honti ${ }^{9}$, Ian D

4 Jones $^{10}$, Nusret Karakaya ${ }^{7}$, Alo Laas ${ }^{11}$, Enrique Moreno-Ostos ${ }^{12}$, Karsten Rinke ${ }^{5}$, Ulrike

5 Scharfenberger ${ }^{13,14}$, Silke R. Schmidt ${ }^{13,15}$, Michael Weber ${ }^{5}$, R. Iestyn Woolway ${ }^{16}$, Jacob A.

6 Zwart $^{17}$, Biel Obrador ${ }^{8}$

7

81 Department of Experimental Limnology, Leibniz-Institute of Freshwater Ecology and

9 Inland Fisheries (IGB), Alte Fischerhütte 2, 16775 Stechlin, Germany

102 Aarhus University, Department of Bioscience, Frederiksborgvej 399, Box 358, 4000

11 Roskilde, Denmark

123 Institute of Biochemistry and Biology, Potsdam University, Maulbeerallee 2, 14469

13 Potsdam, Germany

144 Freshwater Biological Laboratory, Faculty of Science, University of Copenhagen,

15 Universitetsparken 4, 2100 Copenhagen, Denmark

165 Helmholtz-Centre for Environmental Research, Department of Lake Research,

17 Brueckstrasse 3a, 39114 Magdeburg, Germany.

6 Empresa Metropolitana de Abastecimiento y Saneamiento de Aguas de Sevilla, S.A.

EMASESA. C/ Escuelas Pías 1. 41003. Sevilla, Spain

7 Department of Environmental Engineering, Abant Izzet Baysal University, 14280 Bolu,

21 Turkey

Department of Ecology, University of Barcelona, Diagonal 643, 08028 Barcelona, Spain

9 MTA-BME Water Research Group, Hungarian Academy of Sciences, 1111

Budapest, Hungary

${ }^{10}$ Lake Ecosystems Group, Centre for Ecology \& Hydrology, Lancaster Environment Centre, 
11 Estonian University of Life Sciences, Centre for Limnology, Kreutzwaldi 5, Tartu, Estonia

12 Department of Ecology, Marine Ecology and Limnology Research Group, University of Málaga, Campus Universitario de Teatinos S/N. 29071 Málaga, Spain.

13 Leibniz-Institute of Freshwater Ecology and Inland Fisheries (IGB), Department of Ecosystem Research, Müggelseedamm 301, 12587 Berlin, Germany

${ }^{14}$ Freie Universität Berlin, Department of Biology, Chemistry and Pharmacy, Takustraße 3, 14195 Berlin, Germany

15 University of Potsdam, Institute of Earth and Environmental Sciences, Karl-LiebknechtStr. 24-25, 14476 Potsdam, Germany

16 Department of Meteorology, University of Reading, Reading, RG6 6BB, UK.

17 Department of Biological Sciences, University of Notre Dame, Notre Dame, Indiana, 46556 USA

* Corresponding author. Present address: German Centre for Integrative Biodiversity Research (iDiv) Halle-Jena-Leipzig, Deutscher Platz 5e, 04103 Leipzig, Germany, and Institute of Biology, Leipzig University, Johannisallee 21, 04103 Leipzig, Germany Phone: +49 34197 33122, E-mail: darren.giling@idiv.de

\section{Running title: Metabolism in stratified lakes}

Key-words: lake metabolism, gross primary production, ecosystem respiration, ecosystem processes, ecosystem function, organic matter, lake monitoring, high-frequency, buoy data Authorship statement: PAS, BO, DPG, JAZ, LGG, IDJ, RIW, MRA, MH, US, AL \& HPG contributed to the conception of the study; PAS, BO, DPG, NK, FE, JAZ, KR, MW, BB, EMO, CE, US \& SRS acquired the data; DPG analyzed the data and wrote the first draft; all contributed substantially to revisions of and approved the final manuscript. 


\section{Abstract}

Many lakes exhibit seasonal stratification with strong thermal and chemical gradients. An expansion of depth-integrated monitoring programs has provided insight into the importance of organic carbon processing that occurs below the upper mixed layer. However, the chemical and physical drivers of metabolism and metabolic coupling in the metalimnion remain unresolved. Sharp gradients in key resources such as light and temperature co-occur in the metalimnion with dynamic physical conditions that influence metabolic processes directly and simultaneously hamper the accurate tracing of biological activity. We evaluated the drivers of metalimnetic metabolism and its associated uncertainty across ten stratified lakes in Europe and North America. We hypothesized that the metalimnion would contribute highly to wholelake functioning in clear oligotrophic lakes, and that rates would be highly variable in unstable polymictic lakes. Depth-integrated rates of gross primary production (GPP) and ecosystem respiration (ER) were modelled from diel dissolved oxygen curves using a Bayesian approach. Metabolic estimates were more uncertain below the epilimnion, but uncertainty was not consistently related to lake morphology or mixing regime. Metalimnetic rates exhibited high day-to-day variability in all trophic states, with metalimnetic contribution to daily whole-lake GPP and ER ranging from 0 to $87 \%$ and $<1$ to $92 \%$, respectively. Nonetheless, the metalimnion of oligotrophic lakes contributed highly to whole-lake metabolism, driven by a collinear combination of light, phosphorous concentration and metalimnetic volume. Further, higher background respiration was observed in the metalimnion of eutrophic lakes. We show that a single-sensor approach does not necessarily reflect whole-ecosystem carbon dynamics in stratified lakes. 


\section{Introduction}

Globally, many lakes exhibit thermal stratification for a substantial portion of the year, developing marked vertical gradients in physical and chemical properties (Boehrer and Schultze 2008). These gradients influence biological communities and biogeochemical processes such organic and inorganic matter cycling (Coloso et al. 2008; Van de Bogert et al. 2012), altering energy flow through lake food webs (Wilkinson et al. 2014). Consequently, patterns of stratification affect the important contribution that inland waters make to global carbon fluxes (Cole et al. 2007; Coloso et al. 2008; Staehr et al. 2012b). Vertical patterns of ecosystem metabolism vary among chemically and morphologically diverse lakes (Obrador et al. 2014), but information on the drivers of metabolism in the metalimnion is currently limited. However, a recent expansion of high-frequency and depth-integrated monitoring of lakes provides an opportunity to extend our understanding of lake metabolism below the upper mixed layer (epilimnion) (Meinson et al. 2015; Obrador et al. 2014; Staehr et al. 2010). Light availability is a key driver of gross primary production (GPP) below the upper mixed layer (Obrador et al. 2014; Sadro et al. 2011a; Staehr et al. 2012b). Light availability in the metalimnion is determined by two physical factors; the thickness of the epilimnion $\left(\mathrm{Z}_{\mathrm{mix}}\right)$ and light attenuation through the water column $\left(\mathrm{K}_{\mathrm{D}}\right)$. These characteristics vary distinctly among lakes with different chemical characteristics, potentially exerting strong control on metalimnetic processes. Nutrient availability in surface waters controls phytoplankton biomass, so that trophic state and light availability at depth are correlated. Planktonic communities below the epilimnion in eutrophic lakes may be shaded by high plankton densities in upper layers, while stratification reinforces nutrient limitation and relative clarity of surface waters of oligotrophic lakes (Obrador et al. 2014). Nutrient availability may additionally induce induces physiological responses in phytoplankton (e.g. cell size and stoichiometry) that affect their activity rates (Finkel et al. 2010). The chemical influences on GPP propagate to other ecosystem functions. Metabolic coupling between GPP and 
ecosystem respiration (ER) is pronounced under oligotrophic conditions where heterotrophs are substrate-limited and depend on labile photosynthetic exudates (Sadro et al. 2014; Sadro et al. 2011b; Solomon et al. 2013).

In addition to distinct variation among lakes, day-to-day variation in ecosystem metabolism within lakes is substantial (Solomon et al. 2013). The variability differs in magnitude among lakes, and may be related to physical processes determined by lake morphology and mixing regime (Solomon et al. 2013). Periods of stable stratification may facilitate the development of metalimnetic algal communities (Pannard et al. 2015), while unstable and short-term stratification patterns could alter nutrients and OM fluxes, affecting temporal and spatial patterns of metabolic activity. However, attributing biological activity at a specific place and time to physical processes in the metalimnion poses a considerable challenge (Coloso et al. 2011; Staehr et al. 2012a). Biological signals on diel timescales are dampened in the metalimnion, which is a zone characterized by sharp vertical gradients in physical conditions. Therefore, hydrologic processes caused by external forcing (e.g. internal waves and advection; Boegman et al. 2003; Sadro et al. 2011a) need only be minor to contribute substantial noise to diel patterns. Such physical processes alter the spatiotemporal footprint of sensors used to measure the free-water dissolved oxygen (DO) concentrations that are used to estimate metabolic rates (Odum 1956). Thus, physical processes in the metalimnion may simultaneously influence on metabolic processes biologically and affect our ability to accurately trace them with high-frequency measurements.

Understanding the chemical and physical drivers of metalimnetic metabolism and its uncertainty among a diverse lake ecosystems would allow for a more accurate classification of stratified lakes as carbon sources or sinks at the ecosystem scale. We investigated vertical patterns of lake metabolism, photosynthetic light-use efficiency, and the coupling relationship between ER and GPP using high-frequency and depth-specific data from ten lakes and reservoirs that ranged in nutrient concentration and thermal stratification patterns. We used a 
modelling technique that accounted for uncertainty in the estimation of metabolic parameters (following e.g. Batt and Carpenter 2012; Cremona et al. 2014b; Grace et al. 2015; Hanson et al. 2008). This approach offers several advantages; overcoming sources of error present in earlier 'book keeping' methods (McNair et al. 2013), and allowing for the quantification of variation in diel DO that is not explained by the model. We assumed that unexplained variation in diel DO was predominantly attributable to process errors caused by lateral movements of water that are not incorporated in the depth-integrated framework.

We hypothesized that light availability, as described by the ratio of the mixing depth $\left(Z_{\text {mix }}\right)$ to the photic depth $\left(Z_{\mathrm{eu}}\right.$; determined by $\left.K_{\mathrm{D}}\right)\left(\mathrm{i} . e . \mathrm{Z}_{\mathrm{mix}}: \mathrm{Z}_{\mathrm{eu}}\right)$, would control biological processes in the metalimnion (Obrador et al. 2014; Sadro et al. 2011a; Staehr et al. 2012b). The relative contribution of the metalimnion to whole-lake metabolism was expected to be greatest in clear, oligotrophic lakes (i.e. low $\mathrm{Z}_{\text {mix }}: \mathrm{Z}_{\mathrm{eu}}$ ). We sought to identify the conditions where depth-integrated estimates are useful to accurately estimate whole-lake NEP. It was expected that polymictic lakes with a more dynamic thermal structure would exhibit higher temporal variation explained by physical processes. Finally we utilized the depth specific metabolic estimates to investigate vertical patterns in the coupling between GPP and ER. Here we expected a tighter relation in the photic zone, especially in oligotrophic lakes, and ER to be more reliant on recalcitrant OM under low light conditions (Solomon et al. 2013; Obrador et al. 2014).

\section{Methods}

Study sites

We modelled open-water lake metabolism from high-frequency, depth-specific measurements of DO and water temperature $(\mathrm{T})$ in ten lakes and reservoirs across Europe and North America. The dataset included monomictic, dimictic, and polymictic lakes with a range of morphological characteristics and chemical composition (Table 2). Concentration of nutrients, 
154 dissolved organic carbon (DOC) and chlorophyll $a(\mathrm{chl} a)$ were determined from samples taken on 1-11 days at each lake during the stratified period (see Supplemental Text 1 for sampling and analytical methods). In addition, Chl- $a$ concentration was estimated from highrepresented a single year, for a period ranging from several weeks to many months. Only days when the water-column was thermally stratified (as described below) were included in analyses (17 to 69 days per lake).

The profiling systems or sensor chains recorded high-frequency measurements (10-60

min intervals) at 3 to 35 layers in each lake, with at least one measurement point in each depth zone (i.e. epi-, meta- and hypolimnion; Fig. 1; Table S1). We assumed that each measurement represented a horizontal layer of water centred on the measurement depth and having a thickness equal to the vertical resolution of measurements. Therefore, the deepest point of the profile was the depth of the deepest measurement plus half the vertical resolution of that layer. Meteorological data including photosynthetically active radiation (PAR), wind speed and barometric pressure were recorded at the same frequency as sub-surface measurements.

Radiation measurements recorded as irradiance $\left(\mathrm{E} ; \mathrm{W} \mathrm{m}^{-2}\right)$ were converted to photon flux in

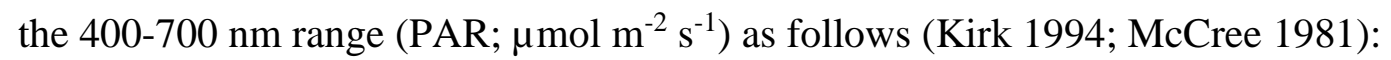

$$
P A R=E \times 4.6 \times 0.45 .
$$

\section{Vertical stratification and underwater light regime}

High vertical resolution $(0.1 \mathrm{~m})$ temperature profiles were modelled from available $\mathrm{T}$ data to

175 determine if a lake was stratified on a given day and to delineate the metalimnion. $\mathrm{T}$ at each depth $z$ was modelled as (Rimmer et al. 2005):

$$
T(z)=T_{h}+\left(T_{e}-T_{h}\right)\left(\frac{1}{1+(\alpha \times z)^{n}}\right)^{1-\left(\frac{1}{n}\right)},
$$


where $T_{e}$ and $T_{h}$ are the maximum temperature in the epilimnion and hypolimnion, respectively, and $\alpha$ and $n$ are model-estimated constants. Temperature curves were fitted in a Bayesian framework with JAGS (Plummer 2003) using normally distributed, maximumentropy priors. The metalimnion extent (i.e. $Z_{\text {mix }}$ to the top of the hypolimnion) was defined using water density $(\rho)$, calculated as:

$$
\rho=1-6.63 \times 10^{-6}(T-4)^{2} .
$$

The gradient in density between adjacent points that defined $\mathrm{Z}_{\text {mix }}$ was selected by visual inspection (Fig. S1) for each lake individually, and ranged between 0.03 and $0.18 \mathrm{~kg} \mathrm{~m}^{-3} \mathrm{~m}^{-1}$ (Read et al. 2011). The bottom of the metalimnion was similarly the deepest point with that density gradient. The sensitivity of metalimnetic volume and depth-zone specific metabolic rates to this gradient was examined at a subset of sites (Lake Ontario, Vedsted and Müggle; see Supplemental Text 2 and Table S2). The thermocline was defined between the points with the greatest density gradient (Read et al. 2011). Mean daily $\mathrm{Z}_{\operatorname{mix}}$ and the bottom of the metalimnion were calculated as the mean values from all profiles on each day, and each layer was assigned to one depth zone (i.e. epi-, meta- or hypolimnion) for each day.

Water-column light attenuation $\left(\mathrm{K}_{\mathrm{D}}\right)$ at each site was calculated from either measurements of underwater PAR at multiple depths, Secchi depth or other existing sitespecific relationships (Table $\mathrm{S} 1$ ). Estimates of $\mathrm{K}_{\mathrm{D}}$ were made from daily to biweekly intervals and were linearly interpolated between measurement days when necessary. Where underwater PAR measurements were available, $\mathrm{K}_{\mathrm{D}}$ was estimated as the slope of the linear regression between $\log (\mathrm{PAR})$ and depth $z$. A mean daily $\mathrm{K}_{\mathrm{D}}$ was calculated from the $\mathrm{K}_{\mathrm{D}}$ of each profile during daylight $\left(\mathrm{PAR}_{0}>5 \mu \mathrm{mol} \mathrm{m} \mathrm{m}^{-2} \mathrm{~s}^{-1}\right)$ that had a linear regression fit with $r^{2}>0.80$ (Obrador et al. 2014; Staehr et al. 2012b). Where Secchi depth was available, $K_{D}$ was calculated as 1.7/Secchi depth (Poole and Atkins 1929). The mean daily photic depth ( $\left.\mathrm{Z}_{\mathrm{eu}}\right)$ was calculated as $4.6 / \mathrm{K}_{\mathrm{D}}$. Following the determination of daily $\mathrm{K}_{\mathrm{D}}$ at each site, PAR for each 
time interval and depth $z\left(\mathrm{PAR}_{\mathrm{z}}\right)$ was calculated from incident PAR $\left(\mathrm{PAR}_{0}\right)$ using the BeerLambert law:

$$
P A R_{z}=P A R_{0} \times e^{-K_{D} \times z}
$$

\section{Model of depth-dependent metabolism}

Gaps in the data series of up to $1 \mathrm{~h}$ were linearly interpolated before we applied a 4-h simple moving average smoothing to DO, PAR and wind speed measurements (following Giling et al. 2016; Obrador et al. 2014). To estimate mean rates of ecosystem metabolism at a daily scale, we used a Bayesian model with non-linear sub-models for GPP and ER (Giling et al. 2016). Changes in DO concentration between successive measurement times $t$ for each depth were partitioned into the contribution by biotic and physical processes using a depth-specific diel oxygen model (Staehr et al. 2012b):

$$
D O(t+1)=D O(t)+N E P(t)-D_{s}(t)-D_{v}(t)+D_{z}(t)
$$

where NEP is the rate of net ecosystem production $\left(\mathrm{mg} \mathrm{O}_{2} \mathrm{~L}^{-1} \mathrm{~h}^{-1}\right), \mathrm{D}_{\mathrm{s}}$ is air-water exchange, $D_{v}$ is diffusive vertical exchange between adjacent depths and $D_{z}$ is metalimnetic exchange due to mixed-layer deepening. Atmospheric exchange $\left(D_{s}\right)$ was applied only to layers in the epilimnion, and calculated as:

$$
D_{s}(t)=K_{s}(t) \frac{D O_{m o d}(t)-D O_{s a t}(t)}{Z_{m i x}(t)}
$$

The gas transfer velocity $\left(K_{S}\right)$ was calculated at a Schmidt number of $600\left(K_{600}\right)$ from wind speed standardized to $10 \mathrm{~m}$ height ( $\left.\mathrm{U}_{10}\right)$ according to Cole and Caraco (1998). In Equation 6, $D O_{m o d}$ is the modelled DO concentration following Song et al. (2016) and $D O_{\text {sat }}$ is DO concentration at atmospheric equilibrium (calculated from temperature and barometric pressure). Vertical exchange between each depth and the adjacent depths due to turbulent diffusivity $\left(D_{v}\right)$ was estimated using the Brunt-Väisälä buoyancy frequency $\left(\mathrm{N}^{2}\left[\mathrm{~s}^{-2}\right]\right.$, a measure of local stability; Boehrer and Schultze 2010) to calculate the vertical eddy 
diffusivity coefficient $\left(\mathrm{K}_{\mathrm{v}}\right)$ according to Hondzo and Stefan (1993). Lake Ontario was an exception due to its surface area exceeding the applicable range of the Hondzo and Stefan (1993) model. The metalimnetic $\mathrm{K}_{\mathrm{v}}$ for Ontario was set as $6 \times 10^{-6} \mathrm{~m}^{2} \mathrm{~s}^{-1}$ based on measurements and theoretical work from Lakes Ontario and Erie (Bouffard et al. 2014; Sweers 1970). Epilimnetic and hypolimnetic $\mathrm{K}_{\mathrm{v}}$ were expected to be higher than the metalimnetic estimate, so were set at Lake Ontario using a factor determined from the average relative difference between depth zones in the other nine lakes. The influence of $K_{v}$ on metabolic rates at Ontario and two other lakes (Vedsted and Müggel) was assessed with a sensitivity analysis (for details see Supplemental Text 2 and Table S2). The flux $D_{z}$ was calculated as proportional to the $\mathrm{Z}_{\text {mix }}$ deepening rate $\left(\Delta Z_{m i x} / \Delta t\right)$ and was applied to measurement points within the metalimnion and $1 \mathrm{~m}$ above or below (Obrador et al. 2014). At some sites, we set a threshold limiting the deepening rate to a maximum of $5 \mathrm{~m} \mathrm{~h}^{-1}$ to prevent short-term surface-water microstratification inaccurately affecting $D_{z}$ in the metalimnion. For a full description of the model, see Staehr et al. (2012b).

Sub-models for the production and respiration components of $N E P$ in Equation 5 were parameterized according to Grace et al. (2015). At each depth, GPP was modelled as a saturating function of $\mathrm{PAR}_{\mathrm{z}}$, while respiration was non-linearly dependent on $T$ for each timestep $t$ :

$$
N E P(t)=A \times P A R(t)^{p}-R_{\bar{T}}\left(\theta^{(T(t)-\bar{T})}\right)
$$

where the first component describes GPP $\left(\mathrm{mg} \mathrm{O}_{2} \mathrm{~L}^{-1} \mathrm{~h}^{-1}\right)$, and $A$ is a constant indicating production per unit light (i.e. photosynthetic efficiency), $P A R$ is the depth-specific PAR $\left(\mathrm{PAR}_{\mathrm{z}}\right)$, and $p$ is an estimated exponent that represents the ability of producers to use light and accounts for saturating photosynthesis (when $p<1$ ). The second component indicates DO consumption by ER $\left(\mathrm{mg} \mathrm{O}_{2} \mathrm{~L}^{-1} \mathrm{~h}^{-1}\right) ; R_{\bar{T}}$ is the respiration rate at $\bar{T}, \theta$ describes the temperature dependence of respiration (set to 1.072, corresponding to $\mathrm{Q}_{10}$ of 2; Wilcock et al. 1998), $T$ is the water temperature at each timestep and $\bar{T}$ is the mean daily temperature in that 
layer. Respiration was estimated at $\bar{T}$ and not standardized because we were interested in vertical patterns among the lakes at in situ conditions. Modelled rates were standardized to a temperature of $20^{\circ} \mathrm{C}\left(\mathrm{GPP}_{20}\right.$ and $\mathrm{ER}_{20}$; for results see Fig. S2) only for analysis of coupling of $\mathrm{ER}_{20}$ to $\mathrm{GPP}_{20}$ (Holtgrieve et al. 2010; Solomon et al. 2013). We estimated the parameters $A$, $p$ and $R_{\bar{T}}$ in Equation 7 for each depth with a Bayesian approach in JAGS (Plummer 2003) using R code (R Development Core Team 2014) modified from Grace et al. (2015) following the rationale of Song et al. (2016). Prior distributions for the estimated parameters were uniformly distributed within known physical constraints as described by Grace et al. (2015). Mean daily metabolic estimates (and their propagated uncertainty) for each depth layer were calculated from estimated parameters as:

$$
\begin{gathered}
G P P=\sum_{t=1}^{\text {measurements }} A \times P A R(t)^{p} \\
E R=86400 \times \frac{R_{\bar{T}}}{\Delta t}
\end{gathered}
$$

where $G P P$ is daily gross primary production $\left(\mathrm{mg} \mathrm{O}_{2} \mathrm{~L}^{-1} \mathrm{~d}^{-1}\right), E R$ is daily ecosystem respiration at daily average temperature $\left(\mathrm{mg} \mathrm{O}_{2} \mathrm{~L}^{-1} \mathrm{~d}^{-1}\right)$ and 86400 converts from seconds to days. Convergence and stationarity of Markov Chain Monte Carlo (MCMC) values were assessed with the Gelman-Rubin convergence statistic $\hat{R}$ (Brooks and Gelman 1997). Models with $\hat{R}>1.1$ (indicating unconverged chains) as well as poor fitting models $\left(r^{2}<0.40\right)$ were excluded from further analyses. Excluding poor fitting models did not substantially alter vertical patterns of ecosystem metabolism or their uncertainty (Fig. S3). Example model fits for each lake are available in the supplementary material (Figs S7-S16) and example code for estimating depth-integrated metabolic rates is available online (github.com/dgiling).

Aggregating layer-specific metabolic rates

Mean daily rates in each depth zone (i.e. epi-, meta- and hypolimnion) were calculated by aggregating the appropriate daily estimates layer from each layer $i$. The standard deviation of 
the aggregated depth zone rate $\left(\sigma_{z o n e}\right)$ was propagated from the modelled uncertainties in layer $i$ as follows:

$$
\sigma_{\text {zone }}=\sqrt{\sum_{i}^{n} \sigma_{i}^{2}}
$$

where $i$ to $n$ are the layers belonging to that depth zone. The aggregated depth-zone estimates were used for further analysis of metabolic rates. Due to high day-to-day variability, only days when there was at least one adequate metabolic model fit (i.e. $\hat{R}<1.1$ and $r^{2}>0.40$ ) from layers in each depth zone (epi-, meta- and hypolimnion when present) were considered to calculate the relative contribution of the metalimnion to whole-lake metabolism (total of 178 days; Table 2).

\section{Whole-lake metabolism estimates}

Whole-lake volume-weighted estimates (WLVW; Sadro et al. 2011a) were calculated by multiplying the daily depth-zone volumetric rates $\left(\mathrm{g} \mathrm{O}_{2} \mathrm{~m}^{-3} \mathrm{~d}^{-1}\right)$ by the total volume $\left(\mathrm{m}^{3}\right)$ of each depth zone before summing the three zones. Metalimnetic volume was calculated using surface areas from hypsographic data and mean daily thickness from high-resolution temperature profiles. Whole-lake areal estimates were then obtained by dividing the WLVW estimate by the lake surface area $\left(\mathrm{m}^{2}\right)$. Hypolimnetic volume and thus metabolic contribution will be underestimated in the small number of lakes that were considerably deeper than the available profile measurements (e.g. Lake Ontario; Table 2). The proportional contribution of the metalimnion to whole-lake metabolism was calculated as the metalimnetic volumetric rate divided by the WLVW estimate (termed 'Propmetab'). We also assessed whether the metalimnion disproportionately contributed metabolic activity for its size (volume) for each day in each lake. We did this by calculating the ratio between the proportion of WLVW metabolism attributable to the metalimnetic (Propmetab) and the metalimnetic contribution to 
whole-lake volume (termed 'Prop ${ }_{\mathrm{vol}}$ '). Thus, the metalimnion contributed more to the whole lake metabolically than it did volumetrically when the ratio Propmetab:Prop vol was $>1$.

We assessed how the traditional metabolism estimates based on single sensors in the epilimnion compared to depth-integrated estimates. 'Single-sensor estimates' were calculated by taking the sensor placed at $1 \mathrm{~m}$ depth, the most widespread DO sensor deployment depth (Solomon et al. 2013), and calculating whole-lake areal metabolism as above assuming that this rate was constant over depth. The shallowest available probe was used when no sensor was available at $1 \mathrm{~m}$ depth.

The 'background respiration' of OM not recently fixed can be inferred from the intercept of the relationship between daily $\mathrm{ER}_{20}$ and daily $\mathrm{GPP}_{20}$, i.e. $\mathrm{ER}_{20}$ when $\mathrm{GPP}_{20}=0$ (del Giorgio and Williams 2005; Solomon et al. 2013). The slope of the relationship between daily $\mathrm{ER}_{20}$ and $\mathrm{GPP}_{20}$ describes the metabolic coupling, where a slope of 1 indicates a unit increase in $\mathrm{ER}_{20}$ for each unit increase in $\mathrm{GPP}_{20}$. The coefficient of determination $\left(r^{2}\right)$ indicates the strength of the coupling (Obrador et al. 2014). We used estimates from layers where there were $>5$ days with successful fits to estimate coupling regression parameters. Models were excluded where the layer was nearly always dark (so that $\mathrm{GPP}_{20}$ was zero or mean $<0.01 \mathrm{mg} \mathrm{O}_{2} \mathrm{~L}^{-1} \mathrm{~d}^{-1}$ ) because the slope was either vertical (and therefore undefined) or highly outlying (20-40 times the mean slope) and not conceptually meaningful. Coupling estimates for depth zone were calculated as the mean of all intercept and slope estimates from layers belonging to that depth zone.

\section{Statistical analyses}

Comparisons among depth zones, correlations with ancillary variables, and $\mathrm{ER}_{20}-\mathrm{GPP}_{20}$ regressions were analyzed by fitting linear models or linear mixed models (LMMs) in R ( R Development Core Team 2014). The LMMs included a random effect for site and layer and AR1 autocorrelation structure (nested within site) to account for repeated daily measurements 
where appropriate. We compared a range of autocorrelation structures (including AR2 and

330 AR3) with Akaike Information Criterion (AIC) values and found AR1 provided equivalent or better support for the models. Reported $r^{2}$ values refer to the variation explained by the fixed effects only. Variables were log-transformed when necessary. Principal components analysis (PCA) was used to reduce the number of collinear explanatory variables, and the resulting components were used as explanatory variables in LMMs to assess potential drivers of metalimnetic contribution.

\section{Results}

\section{Uncertainty in model estimates and contribution of physical processes}

The depth-integrated metabolic model provided a better description of diurnal changes in DO

340 in the epilimnion (74\% of models converged with adequate fit) than in the metalimnion (43\%) or hypolimnion (32\%; Fig. 2a). Furthermore, modelled metabolic estimates were on average more precise in the epilimnion (mean coefficient of variation [CV] for GPP and ER estimates $=0.14$ and 0.23 , respectively) than in the metalimnion (mean GPP and ER CV $=0.25$ and 0.33 , respectively) or hypolimnion (mean GPP and ER CV $=0.35$ and 0.51 , respectively) (Fig. 2b, c). There was high variability in model fit $\left(\mathrm{R}^{2}\right)$ and estimate certainty $(\mathrm{CV})$ among days and depth zones (Fig. 2). In the metalimnion, $\mathrm{R}^{2}$ was unrelated to water-column stability (assessed with the buoyancy frequency $\mathrm{N}^{2} ; \mathrm{F}_{1,470}=1.99, p=0.159 ;$ Fig. S4a). Accordingly, $\mathrm{N}^{2}$ in successful models did not differ from $\mathrm{N}^{2}$ in poor-fitting models (paired $\mathrm{t}$-test, $\mathrm{t}=-0.004, p$ $=0.997$; Fig. S4b). Variation in mean $\mathrm{R}^{2}$ across all lakes and depth zones was also not explained by measurement frequency $\left(\mathrm{F}_{2,25}=0.445, p=0.646\right)$, the vertical resolution of measurements $\left(\mathrm{F}_{1,26}=0.000, p=0.999\right), \mathrm{Z}_{\max }\left(\mathrm{F}_{1,26}=2.11, p=0.159\right)$ or surface area $\left(\mathrm{F}_{1,26}=\right.$ $0.441, p=0.513$; Fig. S5). CV for GPP and ER was also unaffected or only marginally affected by measurement frequency $\left(\mathrm{F}_{2,24}=1.71, p=0.202\right.$ and $\left.\mathrm{F}_{2,25}=3.377, p=0.050\right)$ and the vertical resolution of measurements $\left(\mathrm{F}_{1,26}=0.105, p=0.749\right.$ and $\left.\mathrm{F}_{1,26}=0.167, p=0.898\right)$. 
The physical fluxes of DO (i.e. $D_{s}, D_{v}$ and $D_{z}$ ) contributed a substantial proportion (32 \pm $24 \%$ across all estimates) of the total DO fluxes (i.e. sum of absolute NEP, $D_{s}, D_{v}$ and $D_{z}$ )

(Table S3). In the epilimnion, a mean of $45 \%$ of DO changes were attributable to the diffusive components, mostly atmospheric exchange $\left(D_{s}\right)$ with a small contribution from $D_{v}$ and $D_{z}$. Transfer due to mixed layer deepening $\left(D_{z}\right)$ contributed strongly to the metalimnion (mean $29 \%$ attributable to diffusive fluxes), and both $D_{z}$ and $D_{v}$ estimates were important in the hypolimnion (mean 16\%; Table S3). The average magnitude of physical fluxes was unrelated to mean model $\mathrm{R}^{2}\left(\mathrm{~F}_{1,8}=1.216, p=0.302\right)$ and $\mathrm{CV}$ of GPP and ER estimates among the ten lakes $\left(\mathrm{F}_{1,8}=3.499, p=0.098\right.$ and $\left.\mathrm{F}_{1,8}=2.727, p=0.173\right)$. Further, we did not detect that the physical processes were not strongly affected by lake morphology. In the metalimnion, logtransformed lake area did not affect the balance between $\mathrm{Dz}, \mathrm{Dv}$ and NEP with $\left(\mathrm{F}_{1,8}=1.218\right.$, $p=0.301)$ or without $\left(\mathrm{F}_{1,7}=1.892, p=0.211\right)$ outlying Lake Ontario (Fig. S5). Sensitivity analysis demonstrated that the value of $\mathrm{K}_{\mathrm{v}}$ did not strongly affect metabolic estimates, except for rates in the metalimnion and hypolimnion of polymictic Lake Müggle (Supplemental Text 2 and Table S2).

Metabolic estimates were characterized by high day-to-day variability in some lakes and layers (Fig. 1). For contiguous days with adequate model fits among the ten lakes, between 8$52 \%, 0-78 \%$ and $11-100 \%$ of epi-, meta- and hypolimnetic GPP estimates were within 2 standard deviations (SD) of the estimate from the previous day. Similarly, between 13-53\%, $0-88 \%$ and $11-96 \%$ of epi-, meta- and hypolimnetic ER estimates were within 2 SD of the previous days' estimate. In the metalimnion, this did not appear to be strongly driven by PAR; the day-to-day shift in $\mathrm{PAR}_{\mathrm{z}}$ did not consistently differ between consecutive days that had similar or disparate metabolic estimates. The proportion of days with estimates similar to the previous day was also not related to lake area (Fig. S5). Day-to-day variability in metalimnetic thickness as a proportion of $Z_{\max }$ was slightly higher in polymictic (SD in relative thickness $=0.08 \pm 0.02, n=4$ lakes $)$ than in mono-/dimictic lakes $(\mathrm{SD}=0.04 \pm 0.02$, 
$n=6$ lakes, $\left.\mathrm{F}_{1,8}=6.33, p=0.04\right)$. However, metalimnetic local water-column stability did not

382 differ among mixing regimes $\left(\mathrm{F}_{1,8}=3.26, p=0.109\right)$. The variability daily estimates of GPP and ER in the metalimnion (Table S3) was not related to lake mixing regime $\left(\mathrm{F}_{2,7}=0.753, p=\right.$ 0.505 and $\left.\mathrm{F}_{2,7}=0.044, p=0.957\right)$ or trophic status $\left(\mathrm{F}_{2,7}=1.337, p=0.223\right.$ and $\mathrm{F}_{2,7}=0.178, p$ $=0.841)$. We assessed whether process errors (e.g. lateral water movements) were responsible for high day-to-day variability by testing whether the SD among daily estimates differed when depth-zone means were aggregated from converged models with good $\left(\mathrm{R}^{2}>0.4\right)$ or poor fits $\left(\mathrm{R}^{2}<0.4\right)$. We found was no difference in propagated SD for metalimnetic GPP (paired t-test; $\left.\mathrm{t}_{9}=1.42, p=0.190\right)$ or $\mathrm{ER}\left(\mathrm{t}_{9}=0.772, p=0.460\right)$.

\section{Depth-specific metabolic rates and photosynthetic efficiency}

Vertical patterns of metabolism varied distinctly among the lakes, with mean GPP ranging from 0.00 to $5.98 \mathrm{mg} \mathrm{O}_{2} \mathrm{~L}^{-1} \mathrm{~d}^{-1}$ and ER from 0.00 to $3.74 \mathrm{mg} \mathrm{O}_{2} \mathrm{~L}^{-1} \mathrm{~d}^{-1}$ across all depth zones (Fig. 1; Table S3). Surface layers were most often autotrophic, whilst balanced to net heterotrophic conditions were prevalent in the metalimnion. Mean NEP was $<0 \mathrm{mg} \mathrm{O}_{2} \mathrm{~L}^{-1} \mathrm{~d}^{-1}$ for $60 \%$ of the daily metalimnetic estimates across all the lakes and layers. Mean daily GPP in the epilimnion was positively correlated with mean epilimnetic TP concentration $\left(\mathrm{F}_{1,7}=8.75\right.$, $\left.p=0.021, r^{2}=0.56\right)$, as was epilimnetic ER $\left(\mathrm{F}_{1,7}=10.59, p=0.014, r^{2}=0.60\right)$. In the metalimnion, mean GPP and ER were not linearly correlated to epilimnetic TP concentration $\left(\mathrm{F}_{1,7}=2.04, p=0.196, r^{2}=0.22\right.$ and $\mathrm{F}_{1,7}=0.10, p=0.404, r^{2}=0.10$, respectively; Fig. 3a,b). We found evidence of photosynthetic activity down to $c a .0 .1 \%$ of surface light. Increasing GPP with depth in some lakes was due to higher daily photosynthetic efficiency (i.e. parameter A from Equation 7; GPP $\left[\mathrm{mg} \mathrm{O}_{2} \mathrm{~L}^{-1} \mathrm{~d}^{-1}\right] /$ PAR $\left[\mu \mathrm{mol} \mathrm{m} \mathrm{m}^{-2} \mathrm{sec}^{-1}\right]$ ) in low-light conditions $\left(\mathrm{F}_{1,792}=105.17, p<0.001\right.$; Fig. S6). Correspondingly, photosynthetic efficiency varied by depth $\left(\mathrm{F}_{2,809}=58.55, p<0.001\right)$, and was lower in the epilimnion than in the metalimnion or hypolimnion ( $p<0.01$ in post-hoc pairwise comparisons), which did not 
differ $(p=0.905)$. Photosynthetic efficiency was reduced in low nutrient conditions $\left(\mathrm{F}_{2,23}=\right.$ 25.72, $p<0.001)$. Efficiency was significantly lower in oligotrophic lakes than in mesotrophic lakes (post-hoc comparison; $\mathrm{z}=-4.54, p<0.001$ ), which were lower again than eutrophic lakes $(\mathrm{z}=-3.17, p=0.004)$.

\section{Metalimnetic contribution to whole-lake metabolism}

Across all sites, the proportional contribution of the metalimnion to WLVW metabolic

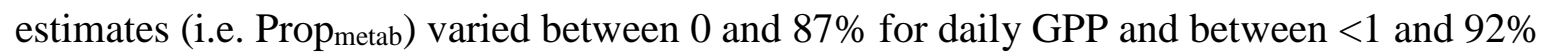

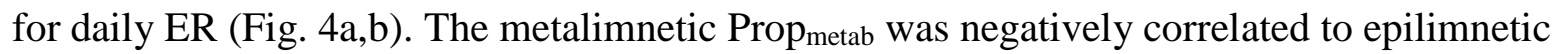
TP concentration for GPP $\left(\mathrm{F}_{1,7}=6.09, p=0.042, r^{2}=0.47\right)$ and for $\mathrm{ER}\left(\mathrm{F}_{1,7}=8.69, p=0.021\right.$, $r^{2}=0.55$ ), but these relationships were driven by Lake Castle (Fig. 3c,d). The proportion of whole-lake volume made up of the metalimnion (i.e. Prop $\mathrm{vol}_{\text {) }}$ ) was between 3 and $60 \%$ (mean $32 \%)$. The metalimnetic Prop metab $_{\text {was positively correlated with metalimnetic Prop }}$ for for both GPP $\left(\right.$ slope $\left.=0.88 \pm 0.12, \mathrm{~F}_{1,175}=58.46, p<0.001, r^{2}=0.25\right)$ and ER $($ slope $=0.94 \pm 0.14$, $\left.\mathrm{F}_{1,175}=43.74, p<0.001, r^{2}=0.20\right)$. The metalimnetic Prop petab:Prop $_{\mathrm{vol}}$ was a mean $0.95 \pm$

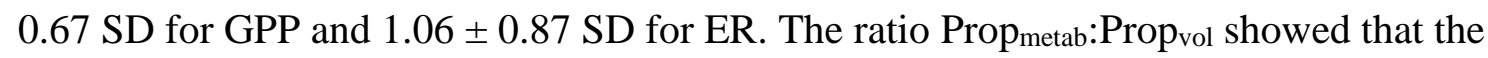
metalimnion disproportionately contributed metabolic activity for its size (i.e. had high Prop $_{\text {metab:Prop }}$ vol) in oligotrophic lakes (Fig. 3e,f). This was evidenced by a negative

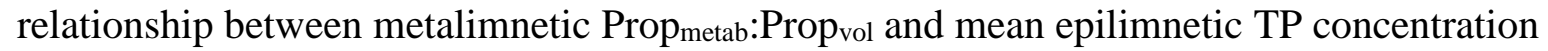
for GPP $\left(\mathrm{F}_{1,7}=15.31, p=0.006, r^{2}=0.68\right.$; Fig. 3e $)$ and $\mathrm{ER}\left(\mathrm{F}_{1,7}=12.46, p=0.010, r^{2}=0.64\right.$; Fig. 3f).

We observed a negative linear correlation between metalimnetic Propmetab and logtransformed $\mathrm{Z}_{\mathrm{mix}}: \mathrm{Z}_{\mathrm{eu}}$ for GPP $\left(\mathrm{F}_{1,166}=12.39, p<0.001\right.$; Fig. 4a). However, this trend was not 430 robust to the exclusion of Lake Castle $\left(\mathrm{F}_{1,151}=2.47, p=0.118\right)$. A similar negative

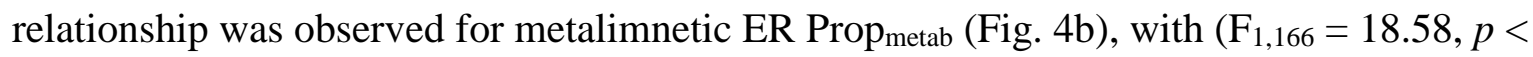
$0.001)$ or without $\left(\mathrm{F}_{1,151}=12.10, p<0.001\right)$ Lake Castle. Comparable trends were observed 
for the effect of log-transformed $\mathrm{Z}_{\mathrm{mix}}: \mathrm{Z}_{\mathrm{eu}}$ on Prop $\mathrm{p}_{\mathrm{metab}}$ :Prop ${ }_{\mathrm{vol}}$, with a negative relationship for

$434 \operatorname{GPP}\left(\mathrm{F}_{1,166}=15.22, p<0.001\right.$; Fig. $\left.4 \mathrm{c}\right)$, which was again not significant when Castle Lake was removed from the analysis $\left(\mathrm{F}_{1,151}=2.08, p=0.151\right)$. In contrast, the negative effect of $\log$-transformed $Z_{\text {mix }}: Z_{\text {eu }}$ on Prop metab:Prop $_{\text {vol }}$ for $E R\left(F_{1,166}=12.46, p<0.001\right.$; Fig. 4d) was robust to the exclusion of Castle Lake $\left(\mathrm{F}_{1,151}=8.31, p=0.005\right)$. Metalimnetic Prop vol $_{\text {vended }}$

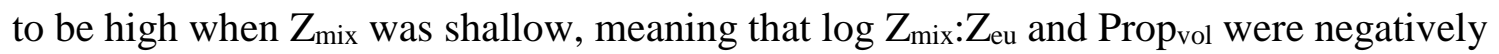
correlated $\left(\mathrm{F}_{1,166}=13.20, p<0.001, r^{2}=0.11\right)$. Hence, we used PCA to examine the collinear drivers of metalimnetic Propmetab. Principal components (PCs) were derived from four variables representing abiotic resource availability and physical conditions $\left(\mathrm{PAR}_{\mathrm{z}}\right.$ temperature, Prop $\mathrm{vol}_{\text {and }} \mathrm{N}^{2}$ ). The PC explaining the majority of variation (PC1) did not reduce the collinearity, as it was characterized by lower temperature, Prop $\mathrm{vol}_{\mathrm{vol}}$ and $\mathrm{N}^{2}$ (Table 3).

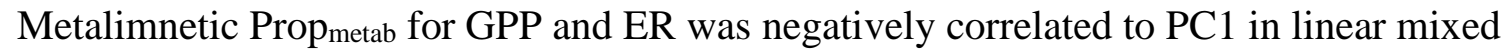
models (Table 3), suggesting a combined importance of these factors. A second component (PC2) was characterized mainly by low light and high local stability $\mathrm{N}^{2}$ in the metalimnion,

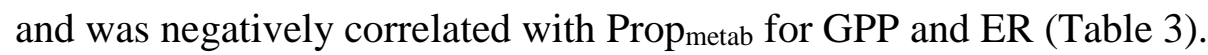

\section{Depth-specific metabolic coupling}

Coupling between $\mathrm{ER}_{20}$ and $\mathrm{GPP}_{20}$ varied among the lakes and depth zones. Background respiration (intercept) ranged from -0.16 to $2.70 \mathrm{mg} \mathrm{O}_{2} \mathrm{~L}^{-1} \mathrm{~d}^{-1}$, mean coupling slope ranged from -0.07 to 1.26 and mean $r^{2}$ varied between 0.05 and 0.94 (Table S4). There was an interaction between the effect of depth zone and epilimnetic TP concentration on mean background respiration $\left(\mathrm{F}_{2,17}=7.19, p=0.005\right)$. Mean epilimnetic TP did not affect mean background respiration in the epilimnion $\left(\mathrm{F}_{1,7}=4.64, \mathrm{p}=0.068\right.$; Fig. 5a), but there was a positive linear correlation in both the metalimnion $\left(\mathrm{F}_{1,7}=26.21, \mathrm{p}=0.002\right.$; Fig. 5b) and hypolimnion $\left(\mathrm{F}_{1,7}=19.19, \mathrm{p}=0.012\right.$; Fig. $\left.5 \mathrm{c}\right)$. The positive relationship in the hypolimnion was driven predominantly by Lake Müggel (Fig. 5c). Across all TP levels, background 
respiration did not differ among depth zones $\left(\mathrm{F}_{2,22}=1.13, p=0.340\right)$. There was no

460 interaction between the effect of epilimnetic $\mathrm{TP}$ and depth zone on the coupling slope $\left(\mathrm{F}_{2,17}=\right.$ $4611.20, p=0.324)$, and no significant difference among depth zones $\left(\mathrm{F}_{2,17}=0.44, p=0.653\right)$.

Across all depth zones, the coupling slope deceased with increasing epilimnetic TP concentration $\left(\mathrm{F}_{1,17}=6.48, p=0.021\right)$, but this relationship was not evident in any one depth zone individually $\left(\mathrm{p}>0.117\right.$; Fig. 5d-f). For the strength of the coupling relationship $\left(r^{2}\right)$ there was also no interaction between the effect of depth zone and mean epilimnetic $\mathrm{TP}\left(\mathrm{F}_{2,17}=\right.$ $0.885, p=0.431)$, and no effect of depth zone $\left(\mathrm{F}_{2,17}=0.023, p=0.977\right)$. The strength of the coupling relationship decreased with increasing TP concentration $\left(\mathrm{F}_{1,17}=7.97, p=0.012\right)$ across all depth zones combined (Fig. 5g-i).

\section{Effect of depth-integration on whole-lake areal NEP estimate}

We assessed how WLWV estimates of GPP, ER and NEP made from a single epilimnetic sensor compared to the depth-integrated estimates. For mean GPP, the single-sensor approach over-estimated whole-lake metabolism at 9 of 10 sites, but the average difference from integrated estimates was variable (mean difference $3.17 \pm 4.58 \mathrm{~g} \mathrm{O}_{2} \mathrm{~m}^{-1} \mathrm{~d}^{-1}$; Fig. 6a). In contrast, single-sensor estimates of ER did not consistently vary from integrated estimates (mean difference $-0.37 \pm 3.40 \mathrm{~g} \mathrm{O}_{2} \mathrm{~m}^{-1} \mathrm{~d}^{-1}$; Fig. 6b). Correspondingly, single-sensor estimates of whole-lake NEP generally were slight overestimates, but there was considerable variation both among lakes and among days within lakes (mean difference $3.55 \pm 6.65 \mathrm{~g} \mathrm{O}_{2} \mathrm{~m}^{-1} \mathrm{~d}^{-1}$; Fig. 6c).

\section{Discussion}

We found contrasting patterns in the vertical structure of metabolic rates among the stratified lakes using a large depth-integrated and high frequency buoy dataset (Fig. 1). In clearer lakes, mean daily rates of GPP and ER were weakly associated with depth (e.g. Lake Bure) or 
peaked in the metalimnion (e.g. Lakes Ontario, Stechlin), as reported before (Sadro et al. 2011a). In contrast, metabolic rates of some mesotrophic and eutrophic lakes were strongly depth-dependent (e.g. Lake Castle; Fig. 1). In lakes with high vertical variation in rates, single-sensor estimates of whole-lake metabolism deviated considerably from depthintegrated estimates on some days (Fig. 6). Despite dissimilar vertical profiles, we found that the metalimnion can contribute substantially to daily whole-lake metabolism across a broad range of lakes, with the exception of highly eutrophic conditions (Figs. $3 \& 4$ ). However, the relative contribution of the metalimnion varied substantially among days regardless of lake

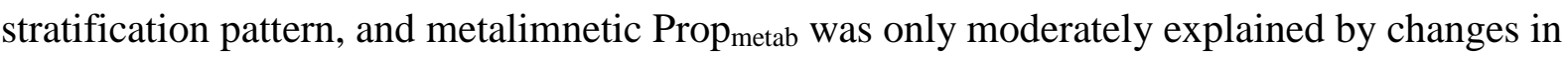

\section{Importance of physical processes to model uncertainty and day-to-day variability}

Our depth-integrated analysis extends current understanding of the role that physical processes play in obtaining accurate metabolic estimates (Coloso et al. 2008; Staehr et al. 2012b; Van de Bogert et al. 2007). Combined with previous sensitivity analyses (Obrador et al. 2014), we show that daily estimates of metabolic rates are robust to uncertainties in vertical diffusive fluxes $\left(D_{v}\right)$ under many circumstances, but there were exceptions in the deeper layers of a polymictic lake (Table S2). This increased sensitivity was likely due to the higher contribution of $\mathrm{D}_{\mathrm{v}}$ and $\mathrm{D}_{\mathrm{z}}$ to DO fluxes in deeper layers and corresponding decrease in the diel signal of DO, water temperature and PAR (Figs S7-S16), as well as model fit (Fig. 2). We expected that high variation in patterns of stratification or low water-column stability would be associated with poor fitting models and uncertainty in parameter estimates.

However, within the metalimnion we found no evidence that polymictic lakes, or days and layers with low stability were associated with poor model convergence or fit. Furthermore, 
model fit and uncertainty were similar among lakes and unrelated to mixing regime (Fig. 2).

512 Hence, while the accuracy of $\mathrm{K}_{\mathrm{v}}$ can influences metabolic results, it does not appear that the magnitude or accuracy of estimated diffusive fluxes are important factors in our ability to accurately describe diel variation in DO. This was supported by total diffusive fluxes (including $\mathrm{D}_{\mathrm{s}}$ ) being high in the epilimnion where model fits were often very good. There are a range of physical processes that were not accounted for by the free-water framework utilized here, including horizontal advection, metalimnetic intrusions and internal seiches caused by wind forcing (Solomon et al. 2013; Van de Bogert et al. 2007). These process errors bring water masses influenced by heterogeneous chemical conditions and biological communities (Solomon et al. 2013; Van de Bogert et al. 2012; Van de Bogert et al. 2007). For example, Sadro et al. (2011a) found that pelagic rates were commonly influenced by littoral habitats due to advection and water-column stability. The patterns of model fits found among depth zones suggested physical process errors were a considerable issue in the meta- and hypolimnion. Because physical processes are a function of lake morphology, we expected the degree of uncertainty to vary among lakes. However, we did not observe any consistent trends in parameters of model fit or importance of diffusive fluxes across our gradient of lake areas (Fig S6), suggesting process areas did not systematically bias our measurement frequency (Table S1).

Physical processes in addition to diffusion may have contributed to the high day-to-day variability in the metabolic estimates because we found little evidence that variability in metalimnetic rates was driven by biological responses (e.g. due to differences in PAR). Conversely, high day-to-day variability is typical even of surface-water metabolic rates that are estimated with higher certainty and better model fits (Solomon et al. 2013; current study). Furthermore, selecting models with good or poor fit did not affect among-day variability or vertical patterns in metabolism (Fig S3). This suggested either that $\mathrm{R}^{2}$ was a poor predictor of 
the importance of process errors, or that process errors did not contribute highly to among-day variability. Quantifying the effect of physical processes on metabolic estimates using freewater measurements remains a considerable challenge and priority for future research.

Ecological inferences made using free-water methods should remain coupled to this consideration (Sadro et al. 2011a) and be interpreted in the context of model fit and uncertainty (Cremona et al. 2014b).

Our results suggest we should remain cautious that patterns in metabolic activity are attributable to biological activity occurring at a certain place and time, especially when stratification periods are not prolonged. However, we employed a number of methods to assist in providing useful information on metabolic processes in the deeper layers of stratified lakes. These included analyzing weeks to months of data for each lake, and using methods such as temporal smoothing and calculating stratification and diffusive fluxes on sub-daily timescales (Coloso et al. 2011) was expected to. Further, where depth-integrated measures of chl- $a$ concentration were available (Table S1), vertical patterns in metabolism generally matched algal biomass. In our study, the vertical resolution of measurements did not affect estimate certainty, but maintaining a high resolution will increase the accuracy of temperature profiles and stratification patterns. This is important for calculating the contribution of specific lake habitats, because metalimnetic contribution was sensitive to its thickness (Supplemental Text 2 and Table S2). Vertical resolution will also assist in cases such as Lake Castle where the development of hypolimnetic hypoxia (Fig. S9) could produce unrealistically sharp diffusive gradients if too few sensors are used.

\section{Vertical patterns in efficiency of light utilization and metabolic coupling}

The increase in light utilization efficiency in deeper depth zones explained the higher GPP rates in the metalimnion despite lower light availability. However, the mechanisms responsible for this pattern may vary among lakes. Chl- $a$ concentration available at multiple 
depths from subset of lakes showed that increases in metalimnetic photosynthetic efficiency at Lakes Hampen, Vedsted, Castle (Obrador et al. 2014) and El Gergal (Table 2) were not caused by higher algal biomass in the metalimnion. This suggests that the phytoplankton communities at depth were physiologically acclimated to the low-light conditions or benefited from the potentially higher nutrient availability and lower temperatures that reduce metabolic costs. In other lakes, such as oligotrophic Lakes Abant and Stechlin, and mesotrophic Lake Bure, chl- $a$ concentration peaked in the metalimnion. Deep chlorophyll maxima (DCM) are a common occurrence in many lakes (e.g. Brentrup et al. in press; Hamilton et al. 2010), and their development will have a strong impact on vertical patterns of metabolism and metabolic coupling. Photosynthetic efficiency may also reflect the physiology of the species comprising the phytoplankton community. Rates of GPP and ER above $\mathrm{Z}_{\mathrm{eu}}$ were conspicuously low at El Gergal for a mesotrophic system, potentially attributable to the dominance by a large, inefficient and slow-growing cyanobacterium (Aphanizomenon flos-aquae; Moreno-Ostos et al. 2016).

\section{Our estimates corroborate with previous findings that heterotrophic to balanced} conditions generally prevail in the metalimnion (e.g. Sadro et al. 2011a), even when it was presumably well lit (Fig. 4e). This has been previously ascribed to ER being less depthdependent than GPP (Coloso et al. 2008). However, vertical patterns in ER were similar to GPP at many sites, at both in situ temperature and when standardized to $20^{\circ} \mathrm{C}$ (Figs. $1 \& \mathrm{~S} 2$ ). Days of autotrophy in the metalimnion of lakes from all trophic states and mixing regimes interspersed the predominant state of heterotrophy (Wilkinson et al. 2015). Despite high variability in GPP and ER rates among sites, metalimnetic NEP was relatively stable (Fig. 4e), with a mean of $-0.08 \pm 0.26 \mathrm{mg} \mathrm{O}_{2} \mathrm{~L}^{-1} \mathrm{~d}^{-1}$ among lakes when excluding Lake Müggle, which had outstandingly high autotrophy in the metalimnion (Fig. 1). This relative stability was likely due to the metalimnetic $\mathrm{ER}_{20}$-to-GPP 20 coupling gradient being close to 1 at many sites (Fig. 5e). Substrate limitation of heterotrophs is hypothesized to drive strong metabolic 
coupling (Sadro et al. 2011b; Solomon et al. 2013), and may be pronounced at depth because

590 the OM in deeper layers typically contains a greater proportion of recalcitrant molecules with 591 low biodegradability (Ostrom et al. 1998). A small number of mean coupling slope estimates

$592>1$ were observed in the meta- and hypolimnion (Fig. 5e, f), suggesting greater than unit

593 increases in ER for each unit increase in GPP. Priming of recalcitrant OM (Guenet et al.

594 2010) could produce such a pattern but evidence for this process in freshwater systems is

595 inconclusive (Catalán et al. 2015). As these high slope estimates all occurred at low GPP it is

596 more likely that these estimates were artificially inflated by statistically influential data points

597 with low GPP relative to ER.

Elevated background respiration in the meta- and hypolimnion of some mesotrophic and eutrophic sites suggests respiration of OM that was not recently or locally produced (Solomon et al. 2013). The metalimnion may be a zone with high degradation of particles that accumulate near the thermocline through a number of co-occurring mechanisms (Staehr et al. 2012b). This includes recently-produced organic material sinking from the epilimnion, combined with large pools of recalcitrant dissolved organic matter (DOM). Other particles such as zooplankton carcasses may be highly available in the metalimnion because they have higher residence times in stratified water columns and move slowly through the thermocline (Kirillin et al. 2012). Particulate organic matter (POM) accumulating below the mixed layer could also originate from resuspension of benthic material by internal seiches during stratification (Weyhenmeyer 1996) or external stream- and groundwater inputs that do not mix with the epilimnion. Higher nutrient availability below the epilimnion may also facilitate greater decomposition rates. For mean heterotrophic conditions, there must be a net subsidy of carbon to the metalimnion and hypolimnion. In addition to accumulating particles, diel vertical migrations could play a role in linking surface and deeper waters, which has been relatively unexplored compared to physical mechanisms. Daily rates of microbial background

614 respiration in the metalimnion could be spatially subsidized by zooplankton that migrate to 
surface waters at night and return to excrete epilimnion-derived DOM and POM at depth (Watras et al. 2015). Furthermore, some motile autotrophs and mixotrophs vertically migrate to the surface to photosynthesize during the day (Salonen et al. 1984), and so respire carbon in deeper waters that was fixed in the surface waters.

\section{Drivers of metalimnetic contribution to whole-lake metabolism}

Contrary to expectations, light conditions in the metalimnion, as measured by the relation between mixing depth and photic zone $\left(Z_{\text {mix }}: Z_{\mathrm{eu}}\right)$, did not explain a large portion of the

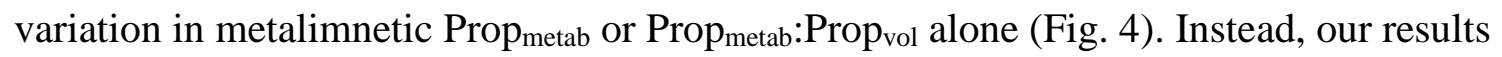
suggested a collinear combination of physical and chemical variables, including light, nutrient concentration, temperature, water-column stability and metalimnetic volume drives

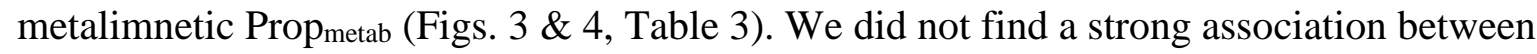

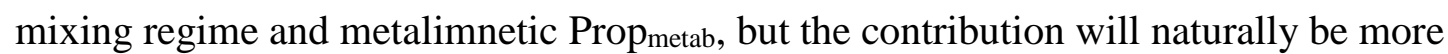
temporally dynamic in polymictic lakes that have interspersed periods of mixed water columns. Concentration of TP in the epilimnion was negatively correlated with metalimnetic Propmetab:Prop $_{\mathrm{vol}}$, likely due to stimulating epilimnetic production that shades metalimnetic organisms (e.g. Laas et al. 2012). However, trends for GPP were highly influenced by the most eutrophic lakes, so that additional sites are required to confirm these patterns. Despite the decreasing metalimnetic Propmetab, absolute rates in the metalimnion increased slowly with TP concentration, until a threshold where the metalimnion was shaded (Castle Lake; Fig. 3a,b). These results imply that eutrophication of lake ecosystems may shift primary production from the metalimnion to the epilimnion, as observed for coastal systems (Lyngsgaard et al. 2014).

The variability in metalimnetic contribution to whole-lake metabolism was highly evident in the range of 0.5 to $1.0 \mathrm{Z}_{\mathrm{mix}}: \mathrm{Z}_{\mathrm{eu}}$ (Fig. 4). While interpolating $\mathrm{K}_{\mathrm{D}}$ could introduce error, such variability was evident even at sites with sub-daily determination of $\mathrm{K}_{\mathrm{D}}$ (e.g. Lake 
641 Stechlin). The dynamic nature of metalimnetic volume on both daily and seasonal bases

642 (Coloso et al. 2011) is likely to affect its contribution to the depth-integrated areal rates

643 (Staehr et al. 2012b). Fluctuations in thermal structure represent not only shifts in light

644 availability, but also potentially important fluxes of OM, nutrients and biota among layers or

645 between sediments and the water column. These fluxes may partly account for the high

646 variability in metabolic estimates at polymictic Lake Müggel, where the longest run of

647 consecutive stratified days was seven. In addition, mixing caused by wind or rain might

648 stimulate metabolism by providing a nutrient or OM subsidy (Giling et al. 2016; Johengen et

649 al. 2008), or depress GPP by suspending OM (Sadro and Melack 2012; Tsai et al. 2008). A

650 key priority to further understand the chemical and physical drivers of variability in the

651 metabolism of stratified lakes is obtaining a greater vertical and temporal resolution of data on

652 nutrient concentration and OM composition (e.g. Watras et al. 2015; Wilkinson et al. 2014).

653 The multiple interacting factors that influence processes below the upper mixed layer

654 suggest that metabolic rates and metalimnetic contribution to whole-lake metabolism may be

655 sensitive to a range of human influences. Anthropogenic changes pervasively affect patterns

656 of thermal stratification and light attenuation in a multitude of ways (Adrian et al. 2009;

657 Carpenter et al. 2011; Tanentzap et al. 2008). For example, climate change may reinforce the

658 thermal stratification and gradually shift mixing regimes (Butcher et al. 2015; Kirillin 2010;

659 Kraemer et al. 2015; Livingstone 2008), while extreme events will disrupt stratification

660 (Jennings et al. 2012). Widespread brownification and cyanobacterial blooms will both shade

661 the water column and alter food-web dynamics (Cremona et al. 2014a; Paerl and Paul 2012;

662 Solomon et al. 2015). In some cases these shifts need only be minor to have a large impact on

663 vertical patterns of metabolism. In particular, biological processes in the metalimnion of lakes

664 with $Z_{\text {mix }}: Z_{\text {eu }}$ close to unity may have little resistance to altered light attenuation or thermal

665 structure. These changes have implications for carbon efflux or storage at regional and even

666 global scales (Tranvik et al. 2009). 
In conclusion, we found that the metalimnion can contribute substantially whole-lake

668 metabolism in many lakes using a depth-integrated approach. However, high variability in

669 rates and collinearity among predictors meant that generalisations about the widespread

670 importance of the metalimnion to water-column processes could not be made with broad lake

671 categories such as trophic status, except for hypereutrophic lakes. Single sensors placed in the

672 epilimnion sensors retain value, especially for investigating the drivers of day-to-day variation

673 in long term records due to high reliability of estimates and relative freedom from process

674 errors. However, single-sensor estimates may not necessarily reflect whole-lake functioning;

675 and deviate from systematically from depth-integrated estimates of GPP. A depth-integrated

676 approach enables enhanced understanding of how physical and biogeochemical processes

677 influence functioning of lake ecosystems as a whole.

678 


\section{References}

Adrian, R. and others 2009. Lakes as sentinels of climate change. Limnol Oceanogr 54: 22832297.

Batt, R. D., and S. R. Carpenter. 2012. Free-water lake metabolism: addressing noisy time series with a Kalman filter. Limnol. Oceanogr. Methods 10: 20-30.

Boegman, L., J. Imberger, G. N. Ivey, and J. P. Antenucci. 2003. High-frequency internal waves in large stratified lakes. Limnol Oceanogr 48: 895-919.

Boehrer, B., and M. Schultze. 2008. Stratification of lakes. Rev. Geophys. 46: RG2005.

Boehrer, B., and M. Schultze. 2010. Density Stratification and Stability. In G. E. Likens [ed.], Lake Ecosystem Ecology: A Global Perspective. Academic Press.

Bouffard, D., L. Boegman, J. D. Ackerman, R. Valipour, and Y. R. Rao. 2014. Near-inertial wave driven dissolved oxygen transfer through the thermocline of a large lake. J Gt Lakes Res 40: 300-307.

Brentrup, J. A. and others in press. Extending the Plankton Ecology Group (PEG) model: The potential of high-frequency profiling to assess vertical and seasonal patterns of phytoplankton dynamics in lakes. Inland Waters.

Brooks, S. P., and A. Gelman. 1997. General methods for monitoring convergence of iterative simulations. Journal of Computational and Graphical Statistics 7: 434-455.

Butcher, J. B., D. Nover, T. E. Johnson, and C. M. Clark. 2015. Sensitivity of lake thermal and mixing dynamics to climate change. Clim Change 129: 295-305.

Carpenter, S. R., E. H. Stanley, and M. J. Vander Zanden. 2011. State of the world's freshwater ecosystems: Physical, chemical, and biological changes. Annual Review of Environment and Resources 36: 75-99.

Catalán, N., A. M. Kellerman, H. Peter, F. Carmona, and L. J. Tranvik. 2015. Absence of a priming effect on dissolved organic carbon degradation in lake water. Limnol Oceanogr 60: 159-168. 
Cole, J. and others 2007. Plumbing the global carbon cycle: Integrating inland waters into the terrestrial carbon budget. Ecosystems 10: 172-185.

Cole, J. J., and N. F. Caraco. 1998. Atmospheric exchange of carbon dioxide in a low-wind oligotrophic lake measured by the addition of SF6. Limnol Oceanogr 43: 647-656.

Coloso, J., J. Cole, and M. Pace. 2011. Short-term variation in thermal stratification complicates estimation of lake metabolism. Aquat Sci 73: 305-315.

Coloso, J. J., J. J. Cole, P. C. Hanson, and M. L. Pace. 2008. Depth-integrated, continuous estimates of metabolism in a clear-water lake. Can J Fish Aquat Sci 65: 712-722.

Cremona, F. and others 2014a. From bacteria to piscivorous fish: estimates of whole-lake and component-specific metabolism with an ecosystem approach. PLoS ONE 9: e101845.

Cremona, F., A. Laas, P. Nõges, and T. Nõges. 2014b. High-frequency data within a modeling framework: On the benefit of assessing uncertainties of lake metabolism. Ecol Modell 294: 27-35.

Del Giorgio, P. A., and P. J. L. B. Williams. 2005. The global significance of respiration in aquatic ecosystems: From single cells to the biosphere. In P. A. del Giorgio and P. J. L. B. Williams [eds.], Respiration in aquatic ecosystems. Oxford University Press.

Finkel, Z. V., J. Beardall, K. J. Flynn, A. Quigg, T. a. V. Rees, and J. A. Raven. 2010. Phytoplankton in a changing world: cell size and elemental stoichiometry. J Plankton Res 32: 119-137.

Giling, D. P. and others 2016. Thermocline deepening boosts ecosystem metabolism: Evidence from a large-scale lake enclosure experiment simulating a summer storm. Glob Change Biol in press.

Grace, M. R., D. P. Giling, S. Hladyz, V. Caron, R. M. Thompson, and R. Mac Nally. 2015. Fast processing of diel oxygen curves: estimating stream metabolism with BASE (BAyesian Single-station Estimation). Limnol. Oceanogr. Methods 13: 103-114. 
Guenet, B., M. Danger, L. Abbadie, and G. Lacroix. 2010. Priming effect: bridging the gap between terrestrial and aquatic ecology. Ecology 91: 2850-2861.

Hamilton, D. P., K. R. O’brien, M. A. Burford, J. D. Brookes, and C. G. Mcbride. 2010. Vertical distributions of chlorophyll in deep, warm monomictic lakes. Aquat Sci 72: 295-307.

Hanson, P. C., S. R. Carpenter, N. Kimura, C. Wu, S. P. Cornelius, and T. K. Kratz. 2008. Evaluation of metabolism models for free-water dissolved oxygen methods in lakes. Limnol. Oceanogr. Methods 6: 454-465.

Holtgrieve, G. W., D. E. Schindler, T. A. Branch, and Z. T. A'mar. 2010. Simultaneous quantification of aquatic ecosystem metabolism and reaeration using a Bayesian statistical model of oxygen dynamics. Limnol Oceanogr 55: 1047-1063.

Hondzo, M., and H. G. Stefan. 1993. Lake water temperature simulation model. Journal of Hydraulic Engineering 119: 1251-1273.

Jennings, E. and others 2012. Effects of weather-related episodic events in lakes: an analysis based on high-frequency data. Freshwater Biol 57: 589-601.

Johengen, T. H., B. A. Biddanda, and J. B. Cotner. 2008. Stimulation of Lake Michigan plankton metabolism by sediment resuspension and river runoff. J Gt Lakes Res 34: 213-227.

Kirillin, G. 2010. Modeling the impact of global warming on water temperature and seasonal mixing regimes in small temperate lakes. Boreal Environ Res 15: 279-293.

Kirillin, G., H.-P. Grossart, and K. W. Tang. 2012. Modeling sinking rate of zooplankton carcasses: Effects of stratification and mixing. Limnol Oceanogr 57: 881-894.

Kirk, J. T. 1994. Light and photosynthesis in aquatic ecosystems. Cambridge University Press.

Kraemer, B. M. and others 2015. Morphometry and average temperature affect lake stratification responses to climate change. Geophys. Res. Lett. 42: 2015 GL064097. 
Laas, A., P. Nõges, T. Kõiv, and T. Nõges. 2012. High-frequency metabolism study in a large and shallow temperate lake reveals seasonal switching between net autotrophy and net heterotrophy. Hydrobiologia 694: 57-74.

Livingstone, D. M. 2008. A Change of Climate Provokes a Change of Paradigm: Taking Leave of Two Tacit Assumptions about Physical Lake Forcing. Int Rev Hydrobiol 93: 404-414.

Lyngsgaard, M. M., S. Markager, and K. Richardson. 2014. Changes in the vertical distribution of primary production in response to land-based nitrogen loading. Limnol Oceanogr 59: 1679-1690.

Mccree, K. J. 1981. Photosynthetically active radiation. In O. L. Lang, P. Novel, B. Osmond and H. Ziegler [eds.], Physiological plant ecology. Encyclopedia of plant physiology (new series). Springer-Verlag.

Mcnair, J. N., L. C. Gereaux, A. D. Weinke, M. R. Sesselmann, S. T. Kendall, and B. A. Biddanda. 2013. New methods for estimating components of lake metabolism based on free-water dissolved-oxygen dynamics. Ecol Modell 263: 251-263.

Meinson, P., A. Idrizaj, P. Nõges, T. Nõges, and A. Laas. 2015. Continuous and highfrequency measurements in limnology: history, applications, and future challenges. Environ Rev 24: 52-62.

Moreno-Ostos, E., R. L. Palomino-Torres, C. Escot, and J. M. Blanco. 2016. Planktonic metabolism in a Mediterranean reservoir during a near-surface cyanobacterial bloom. Limnetica 35: 117-130.

Obrador, B., P. A. Staehr, and J. P. C. Christensen. 2014. Vertical patterns of metabolism in three contrasting stratified lakes. Limnol Oceanogr 59: 1228-1240.

Odum, H. T. 1956. Primary production in flowing waters. Limnol Oceanogr 1: 102-117. 
Ostrom, N. E., D. T. Long, E. M. Bell, and T. Beals. 1998. The origin and cycling of particulate and sedimentary organic matter and nitrate in Lake Superior. Chemical Geology 152: 13-28.

Paerl, H. W., and V. J. Paul. 2012. Climate change: Links to global expansion of harmful cyanobacteria. Water Res. 46: 1349-1363.

Pannard, A., D. Planas, and B. E. Beisner. 2015. Macrozooplankton and the persistence of the deep chlorophyll maximum in a stratified lake. Freshwater Biol 60: 1717-1733.

Plummer, M. 2003. JAGS: A program for analysis of Bayesian graphical models using Gibbs sampling. Proceedings of the 3rd International Workshop on Distributed Statistical Computing (DSC 2003).

Poole, H. H., and W. R. G. Atkins. 1929. Photoelectric measurements of submarine illumination throughout the year. J Mar Biol Assoc U K 16: 297-324.

R Development Core Team. 2014. R: A language and environment for statistical computing. R Foundation for Statistical Computing, Vienna, Austria. ISBN 3-900051-07-0, URL http://www.R-project.org.

Read, J. S. and others 2011. Derivation of lake mixing and stratification indices from highresolution lake buoy data. Environmental Modelling and Software 26: 1325-1336.

Rimmer, A., Y. Aota, M. Kumagai, and W. Eckert. 2005. Chemical stratification in thermally stratified lakes: A chloride mass balance model. Limnol Oceanogr 50: 147-157.

Sadro, S., G. W. Holtgrieve, C. T. Solomon, and G. R. Koch. 2014. Widespread variability in overnight patterns of ecosystem respiration linked to gradients in dissolved organic matter, residence time, and productivity in a global set of lakes. Limnol Oceanogr 59: $1666-1678$.

Sadro, S., and J. Melack. 2012. The effect of an extreme rain event on the biogeochemistry and ecosystem metabolism of an oligotrophic high-elevation lake. Arct. Antarct. Alp. Res. 44: 222-231. 
Sadro, S., J. M. Melack, and S. Macintyre. 2011a. Depth-integrated estimates of ecosystem metabolism in a high-elevation lake (Emerald Lake, Sierra Nevada, California). Limnol Oceanogr 56: 1764-1780.

Sadro, S., C. E. Nelson, and J. M. Melack. 2011b. Linking diel patterns in community respiration to bacteriplankton in an oligotrophic high-elevation lake. Limnol Oceanogr 56: $540-550$.

Salonen, K., R. I. Jones, and L. Arvola. 1984. Hypolimnetic phosphorus retrieval by diel vertical migrations of lake phytoplankton. Freshwater Biol 14: 431-438.

Solomon, C. and others 2015. Ecosystem consequences of changing inputs of terrestrial dissolved organic matter to lakes: Current knowledge and future challenges. Ecosystems 18: 376-389.

Solomon, C. T. and others 2013. Ecosystem respiration: Drivers of daily variability and background respiration in lakes around the globe. Limnol Oceanogr 58: 849-866.

Song, C., W. K. Dodds, M. T. Trentman, J. Rüegg, and F. Ballantyne. 2016. Methods of approximation influence aquatic ecosystem metabolism estimates. Limnol. Oceanogr. Methods 14: 557-569.

Staehr, P., J. Testa, W. Kemp, J. Cole, K. Sand-Jensen, and S. Smith. 2012a. The metabolism of aquatic ecosystems: history, applications, and future challenges. Aquat Sci 74: 1529.

Staehr, P. A. and others 2010. Lake metabolism and the diel oxygen technique: State of the science. Limnol. Oceanogr. Methods 8: 628-644.

Staehr, P. A., J. P. A. Christensen, R. D. Batt, and J. S. Read. 2012b. Ecosystem metabolism in a stratified lake. Limnol Oceanogr 57: 1317-1330.

Sweers, H. E. 1970. Vertical diffusivity coefficient in a thermocline. Limnol Oceanogr 15: 273-280. 
Tanentzap, A. J. and others 2008. Cooling lakes while the world warms: Effects of forest regrowth and increased dissolved organic matter on the thermal regime of a temperate, urban lake. Limnol Oceanogr 53: 404-410.

Tranvik, L. J. and others 2009. Lakes and reservoirs as regulators of carbon cycling and climate. Limnol Oceanogr 54: 2298-2314.

Tsai, J.-W. and others 2008. Seasonal dynamics, typhoons and the regulation of lake metabolism in a subtropical humic lake. Freshwater Biol 53: 1929-1941.

Van De Bogert, M. C. and others 2012. Spatial heterogeneity strongly affects estimates of ecosystem metabolism in two north temperate lakes. Limnol Oceanogr 57: 1689-1700.

Van De Bogert, M. C., S. R. Carpenter, J. J. Cole, and M. L. Pace. 2007. Assessing pelagic and benthic metabolism using free water measurements. Limnol. Oceanogr. Methods 5: $145-155$.

Watras, C. J., K. A. Morrison, J. T. Crawford, C. P. Mcdonald, S. K. Oliver, and P. C. Hanson. 2015. Diel cycles in the fluorescence of dissolved organic matter in dystrophic Wisconsin seepage lakes: Implications for carbon turnover. Limnol Oceanogr 60: 482-496.

Weyhenmeyer, G. A. 1996. The influence of stratification on the amount and distribution of different settling particles in Lake Erken. Canadian Journal of Fishereis and Aquatic Sciences 53: 1254-1262.

Wilcock, R. J. J. W. N., G. B. Mcbride, K. J. Collier, B. T. Wilson, and B. A. Huser. 1998. Characterisation of lowland streams using a single-station diel curve analysis model with continuous monitoring data for dissolved oxygen. New Zeland Journal of Marine and Freshwater Research 32: 67-79.

Wilkinson, G. M., S. R. Carpenter, J. J. Cole, and M. L. Pace. 2014. Use of deep autochthonous resources by zooplankton: Results of a metalimnetic addition of ${ }^{13} \mathrm{C}$ to a small lake. Limnol Oceanogr 59: 986-996. 
857 Wilkinson, G. M., J. J. Cole, M. L. Pace, R. A. Johnson, and M. J. Kleinhans. 2015. Physical 858 and biological contributions to metalimnetic oxygen maxima in lakes. Limnol Oceanogr 60: 242-251.

860 


\section{Acknowledgements}

862 The collaboration was made possible by the activities of Networking Lake Observations in 863 Europe (NETLAKE), funded by the European Corporation in Science and Technology 864 (COST) action ES1201. Ideas for this manuscript were initiated at a NETLAKE workshop 865 organized by PAS, BO and E. Jennings in Roskilde, Denmark. Acquisition of Lake Stechlin 866 data was facilitated by grants from the German Federal Ministry of Education and Research 867 (BMBF; no. 033L041B) and the German Research Foundation (DFG Core Facility; no. GE 1775/2-1) to M.O. Gessner, and from the Leibniz Association (project 'TemBi'; SAW-2011IGB-2) to P. Casper and HPG. We thank S. A. Berger, C. Engelhardt, M.O. Gessner, M. Lentz, J. C. Nejstgaard and A. Penske for acquisition of ancillary data from Lake Stechlin. Data from Danish lakes were supported by the Danish Centre for Lake Restoration (CLEAR). Data collection from Lake Abant was funded by the Scientific and Technological Research Council of Turkey (TUBITAK) (Grant No: 111Y059). Data collection for El Gergal Reservoir was supported by EMASESA and projects EU- ENV/UK/000604 and CGL200504070. Lake Ontario data was provided by B. Weidel and M. Paufve and funding for data 876 collection at Lake Ontario came from the Great Lakes Restoration Initiative, Great Lakes 877 Fishery Commission, and New York State Department of Conservation. Two anonymous reviewers provided comments that greatly improved this manuscript. 
Table 1. Description of acronyms and terms

\begin{tabular}{|c|c|c|}
\hline $\begin{array}{l}\text { Parameter or } \\
\text { acronym }\end{array}$ & Description & Unit \\
\hline $\mathrm{OM}$ & Organic Matter & \\
\hline GPP & Gross Primary Production at in situ temperature & $\mathrm{mg} \mathrm{O}_{2} \mathrm{~L}^{-1} \mathrm{~d}^{-1}$ \\
\hline $\mathrm{GPP}_{20}$ & Gross Primary Production standardized to $20^{\circ} \mathrm{C}$ & $\mathrm{mg} \mathrm{O}_{2} \mathrm{~L}^{-1} \mathrm{~d}^{-1}$ \\
\hline ER & Ecosystem Respiration at in situ temperature & $\mathrm{mg} \mathrm{O}_{2} \mathrm{~L}^{-1} \mathrm{~d}^{-1}$ \\
\hline $\mathrm{ER}_{20}$ & Ecosystem Respiration standardized to $20^{\circ} \mathrm{C}$ & $\mathrm{mg} \mathrm{O}_{2} \mathrm{~L}^{-1} \mathrm{~d}^{-1}$ \\
\hline $\begin{array}{l}\text { Background } \\
\text { respiration }\end{array}$ & $\begin{array}{l}\text { Respiration of OM not recently or locally fixed; the intercept of the } \\
\text { correlation between ER } 20 \text { and GPP20 }\end{array}$ & $\mathrm{mg} \mathrm{O}_{2} \mathrm{~L}^{-1} \mathrm{~d}^{-1}$ \\
\hline NEP & $\begin{array}{l}\text { Net Ecosystem Production (GPP-ER); describes whether the layer } \\
\text { or lake is net autotrophic or net heterotrophic }\end{array}$ & $\mathrm{mg} \mathrm{O}_{2} \mathrm{~L}^{-1} \mathrm{~d}^{-1}$ \\
\hline $\mathrm{TP}$ & Total Phosphorous & $\mu g \mathrm{~L}^{-1}$ \\
\hline $\mathrm{TN}$ & Total Nitrogen & $\mu \mathrm{g} \mathrm{L}^{-1}$ \\
\hline DO & $\mu g \mathrm{~L}^{-1}$ & $\mathrm{mg} \mathrm{L}^{-1}$ \\
\hline$Z_{\text {mix }}$ & Mixing depth; bottom of the epilimnion and top of the metalimnion & $\mathrm{m}$ \\
\hline $\mathrm{Z}_{\mathrm{eu}}$ & Photic depth; equal to depth with $1 \%$ of surface light & $\mathrm{m}$ \\
\hline $\mathrm{Z}_{\text {mix }}: \mathrm{Z}_{\mathrm{eu}}$ & $\begin{array}{l}\text { Ratio of mixing to photic depth. Describes light availability in the } \\
\text { metalimnion }\end{array}$ & \\
\hline $\mathrm{T}$ & Temperature & ${ }^{\circ} \mathrm{C}$ \\
\hline DOC & Dissolved Organic Carbon & $\mathrm{mg} \mathrm{L}^{-1}$ \\
\hline Chl $a$ & Chlorophyll- $a$ concentration & $\mu g L^{-1}$ \\
\hline DCM & Deep Chlorophyll Maximum & \\
\hline $\mathrm{PAR}_{0}$ & Incoming surface Photosynthetic Active Radiation & $\mu \mathrm{mol} \mathrm{m}-2 \mathrm{~s}^{-1}$ \\
\hline $\mathrm{PAR}_{\mathrm{z}}$ & Photosynthetic Active Radiation at depth $\mathrm{z}$ & $\mu \mathrm{mol} \mathrm{m}{ }^{-2} \mathrm{~s}^{-1}$ \\
\hline $\mathrm{K}_{\mathrm{D}}$ & Light attenuation coefficient & $\mathrm{m}^{-1}$ \\
\hline $\mathrm{U}_{10}$ & Wind speed at $10 \mathrm{~m}$ above surface of lake & $\mathrm{m} \mathrm{s}^{-1}$ \\
\hline $\mathrm{D}_{\mathrm{s}}$ & Atmospheric & $\mathrm{mg} \mathrm{O}_{2} \mathrm{~L}^{-1} \mathrm{~h}^{-1}$ \\
\hline$D_{v}$ & $\begin{array}{l}\text { Vertical exchange between each depth and the adjacent depths due } \\
\text { to turbulent diffusivity }\end{array}$ & $\mathrm{mg} \mathrm{O}_{2} \mathrm{~L}^{-1} \mathrm{~h}^{-1}$ \\
\hline $\mathrm{N}^{2}$ & Brunt-Väisälä buoyancy frequency & $\mathrm{s}^{-2}$ \\
\hline $\mathrm{K}_{\mathrm{v}}$ & Vertical eddy diffusivity coefficient & \\
\hline$D_{z}$ & Exchange due to mixed-layer deepening & $\mathrm{mg} \mathrm{O}_{2} \mathrm{~L}^{-1} \mathrm{~h}^{-1}$ \\
\hline WLVW & $\begin{array}{l}\text { Whole-lake volume-weighted estimate of metabolism (Sadro et al. } \\
\text { 2011a) }\end{array}$ & $\mathrm{g} \mathrm{O}_{2} \mathrm{~m}^{-3} \mathrm{~d}^{-1}$ \\
\hline Propmetab & Proportion of WLWV metabolism occurring in a certain depth zone & \\
\hline Prop $_{\mathrm{vol}}$ & Proportion of whole lake volume occurring in a certain depth zone & \\
\hline $\begin{array}{l}\text { Prop }_{\text {metab }}: \\
\text { Prop }_{\text {vol }}\end{array}$ & $\begin{array}{l}\text { Ratio of proportion metabolism to proportion volume; ratio is }>1 \\
\text { when a depth zone contributes more metabolically than it does } \\
\text { volumetrically }\end{array}$ & \\
\hline
\end{tabular}


Table 2. Site information and ancillary data for the ten study lakes. Chemical and biological data are mean measurements from 1-11 samples among measurements are presented in Table S1). The column '\# days (total)' shows the total number of stratified days with metabolic estimates in each

lake, with the number of days with at least one successful model fit in each depth zone (epi-, meta- and hypolimnion) in brackets.

\begin{tabular}{|c|c|c|c|c|c|c|c|c|c|c|c|c|c|}
\hline \multirow{2}{*}{ Lake } & \multirow{2}{*}{ Location } & \multirow{2}{*}{ \# days } & \multirow{2}{*}{$\begin{array}{l}\text { Trophic } \\
\text { status }\end{array}$} & \multirow{2}{*}{$\begin{array}{l}\text { Mixing } \\
\text { regime }\end{array}$} & \multirow{2}{*}{$\begin{array}{c}\text { Max. } \\
\text { depth } \\
\text { (lake) } \\
\text { m }\end{array}$} & \multirow{2}{*}{$\begin{array}{c}\text { Max. depth } \\
\text { (profile) } \\
\text { m }\end{array}$} & \multirow{2}{*}{$\begin{array}{c}\text { Mean } \\
\mathrm{Z}_{\text {mix }} \\
\text { m }\end{array}$} & \multirow{2}{*}{$\begin{array}{c}\text { Mean } \\
Z_{\mathrm{eu}} \\
\text { m }\end{array}$} & \multirow{2}{*}{$\begin{array}{c}\text { Mean } \\
\text { meta. } \\
\text { thickness } \\
\text { m }\end{array}$} & \multirow{2}{*}{$\begin{array}{c}\text { Epi. } \\
\text { TP } \\
\mu \mathrm{g} \mathrm{L}^{-1}\end{array}$} & \multirow{2}{*}{$\begin{array}{l}\text { Epi. } \\
\text { TN } \\
\mu \mathrm{g} \mathrm{L}^{-1}\end{array}$} & \multirow{2}{*}{$\begin{array}{l}\text { Epi. } \\
\text { DOC } \\
\mu \mathrm{g} \mathrm{L}^{-1}\end{array}$} & \multirow{2}{*}{$\begin{array}{l}\text { Epi. } \\
\text { Chl } a \\
\mu \mathrm{g} \mathrm{L}^{-1}\end{array}$} \\
\hline & & & & & & & & & & & & & \\
\hline Abant & Turkey & $17(2)$ & oligo. & mono. & 18 & 12.75 & 5.6 & 11.9 & 2.6 & 14.0 & 1.5 & & 1.5 \\
\hline Ontario & United States & $69(17)$ & oligo. & mono. & 244 & 35 & 10.3 & 23.2 & 10.3 & 6.4 & & & 0.7 \\
\hline Stechlin & Germany & $41(32)$ & oligo. & di. & 69.5 & 17.25 & 6.8 & 12.7 & 5.1 & 12.2 & 0.4 & 5.0 & 1.9 \\
\hline $\begin{array}{l}\text { Rappbode } \\
\text { pre-dam }\end{array}$ & Germany & $48(19)$ & meso. & di. & 17 & 15.75 & 2.6 & 4.7 & 4.7 & 25.2 & 0.7 & 4.8 & 9.4 \\
\hline Bure & Denmark & $58(29)$ & meso. & poly. & 11 & 9.5 & 4.3 & 7.5 & 3.3 & 22.9 & 0.7 & & 5.5 \\
\hline Hampen & Denmark & $56(15)$ & meso. & poly. & 13 & 9.5 & 4.4 & 6.3 & 3.1 & 23.6 & 0.6 & 3.0 & 8.7 \\
\hline El Gergal & Spain & $21(17)$ & meso. & mono. & 37 & 19.75 & 5.3 & 6.5 & 6.1 & & & & 24.1 \\
\hline Vedsted & Denmark & $60(14)$ & eu. & di. & 11 & 9.5 & 3.5 & 4.0 & 3.8 & 27.3 & 0.5 & 4.9 & 41.4 \\
\hline Müggel & Germany & $28(17)$ & eu. & poly. & 7.7 & 5.25 & 1.5 & 3.0 & 2.0 & 63.5 & 0.8 & 7.2 & 35.3 \\
\hline Castle & Denmark & $32(16)$ & hypereu. & poly. & 9 & 8.5 & 4.4 & 2.3 & 2.6 & 94.1 & 1.6 & 3.4 & 46.3 \\
\hline
\end{tabular}


Table 3. Results of principal components analysis (PCA). 'Linear mixed models' rows indicate the results of linear models using the components as

891 explanatory variables to explain metalimnetic contribution to whole-lake areal GPP and ER (Propmetab). ' $\beta$ ' indicates the estimated slope of the

892 linear model.

\begin{tabular}{lcc}
\hline \multicolumn{1}{c}{ Principal component } & PC1 & PC2 \\
\hline \% variation explained & 36 & 32 \\
& & \\
Axis rotation & & -0.42 \\
$\quad$ Metalimnetic Prop & & -0.65 \\
Mean metalimnetic log PAR & -0.52 & 0.19 \\
Mean metalimnetic layer temperature & -0.26 & 0.60
\end{tabular}

Linear mixed models

Prop $_{\text {metab }}$ for GPP

$\begin{array}{cc}\beta=-0.11 \pm 0.01 & \beta=-0.02 \pm 0.02 \\ p<0.001, \mathrm{r}^{2}=0.26 & p=0.200, \mathrm{r}^{2}=0.08 \\ \beta=-0.07 \pm 0.02 & \beta=-0.10 \pm 0.02 \\ p<0.001, \mathrm{r}^{2}=0.09 & p<0.001, \mathrm{r}^{2}=0.15\end{array}$


894 Figure 1. Mean ( \pm SD among days) depth-specific volumetric estimates of daily GPP (open 895 white points) and ER (closed grey points) of adequately fit models over stratified days at each lake. The grey rectangle indicates the mean extent of metalimnion and the dashed black line indicates the mean daily $\mathrm{Z}_{\mathrm{eu}}$.

Figure 2. Scatterplots of mean $( \pm \mathrm{SD})(\mathrm{a}) \mathrm{R}^{2}$, (b) coefficient of variation $(\mathrm{CV})$ of GPP estimates, and (c) CV of ER estimates from all models across the study lakes and depth zones. White, grey and black points show epi-, meta- and hypolimnetic zones respectively. Value above the dashed horizontal line at $\mathrm{R}^{2}=0.40$ in panel (a) were considered to have adequate model fit.

Figure 3. Scatterplots showing the correlation between mean $( \pm \mathrm{SD})$ epilimnetic total phosphorus (TP) and metalimnetic GPP (left) and ER (right). Plots show mean ( \pm SD) metalimnetic volumetric rates $(a, b)$, mean relative contribution of the metalimnion to WLVW metabolic estimates (i.e. Prop metab; $_{\text {c,d); }}$ and the ratio between Propmetab and the relative contribution of the metalimnetic volume to whole-lake volume (Prop metab $_{\text {: Prop }}$ vol; e,f). Solid black lines indicate significant linear relationships in linear mixed models. White, grey and black points indicate oligotrophic, mesotrophic and eutrophic lakes, respectively. Circles, squares/diamonds and triangles represent monomictic, dimictic and polymictic lakes, respectively.

Figure 4. Scatterplots showing the correlation between $\mathrm{Z}_{\text {mix }}: \mathrm{Z}_{\mathrm{eu}}$ and metalimnetic metabolism. The top row shows the proportional contribution of the metalimnion to WLVW metabolic estimates (Propmetab) for (a) GPP and (b) ER. The middle row shows the effect of $Z_{\text {mix }}: Z_{\text {eu }}$ on the ratio between Propmetab and the proportion contribution of the metalimnetic volume to 
whole-lake volume (Propmetab:Prop ${ }_{\text {vol }}$ ) for (c) GPP and (d) ER. At values higher than the

920 dashed horizontal line at Prop $\mathrm{petab}_{\mathrm{Prop}} \mathrm{Pol}_{\mathrm{v}}=1$ the metalimnion contributes more to the whole lake metabolically than it does volumetrically. Panel (e) shows the volumetric rate of NEP as a function of mean daily $Z_{\text {mix }}: Z_{\mathrm{eu}}$. Each point represents one day, with a point only for days with at least one appropriate model fit in each depth-zone shown for plots a-d. White, grey and black points indicate oligotrophic, mesotrophic and eutrophic lakes, respectively. Circles, squares and triangles represent monomictic, dimictic and polymictic lakes, respectively. In plots $\mathrm{c}$ and d some outlying high points at Lake Ontario were excluded to assist interpretation.

Figure 5. Scatterplots of the correlation between and nutrient concentration on $\mathrm{ER}_{20}$-to-GPP 20 coupling in the epi- (left), meta- (centre) and hypolimnion (right). The top row shows the effect of mean $( \pm \mathrm{SD})$ epilimnetic TP on mean $( \pm \mathrm{SD})$ background respiration (i.e. intercept of correlation; $\mathrm{mg} \mathrm{O}_{2} \mathrm{~L}^{-1} \mathrm{~d}^{-1}$ ) in all depth zones. The dashed horizontal line indicate a background respiration of zero (conceptually no ER independent of GPP), and the solid lines show significant relationships in LMMs. The centre row shows the relationship of TP with coupling slope $\left(\mathrm{mg} \mathrm{O}_{2} \mathrm{~L}^{-1} \mathrm{~d}^{-1}\right)$, with the dashed line at a slope of unity (representing a unit increase in ER for each in GPP). The bottom row shows the correction of mean TP with coupling strength $\left(r^{2}\right)$. White, grey and black points indicate oligotrophic, mesotrophic and eutrophic lakes, respectively. Circles, squares and triangles represent monomictic, dimictic and polymictic lakes, respectively.

Figure 6. Comparison of mean $( \pm \mathrm{SD})$ daily whole-lake volume weighted (WLVW) metabolism between depth-integrated and single-sensor estimates of (a) GPP, (b) ER and (c) NEP. The dashed line indicates the 1:1 relationship. White, grey and black points indicate oligotrophic, mesotrophic and eutrophic lakes, respectively. Circles, squares and triangles represent monomictic, dimictic and polymictic lakes, respectively. 